\title{
HOW SOCIAL MEDIA AFFORDS POPULIST POLITICS: REMARKS ON LIMINALITY BASED ON THE BRAZILIAN CASE
}

\section{COMO AS MÍDIAS SOCIAIS PROPORCIONAM UMA POLITICA POPULISTA: OBSERVAÇÕES SOBRE LIMINARIDADE COM BASE NO CASO BRASILEIRO}

\section{Leticia Cesarino*}

\begin{abstract}
In the past decade or so, populism and social media have been outstanding issues both in academia and the public sphere. At this point, evidence from multiple countries suggest that perceived parallels between the dynamics of social media and the mechanics of populist discourse may be more than just incidental, relating to a shared structural field. This article suggests one possible path towards making sense of how the dynamics of social media and the mechanics of populist mobilization have co-produced each other in the last decade or so. Navigating the interface between anthropology and linguistics, it takes key aspects of Victor Turner's notion of liminality to suggest some of the ways in which social media's anti-structural affordances may help lay a foundation for the contemporary flourishing of populist discourse: markers of social structure are suspended; communitas is formed; the culture core is addressed; mimesis and anti-structural inversions are performed; subjects become influenceable. I elaborate on this claim based on Brazilian materials, drawn from online ethnography on pro-Bolsonaro WhatsApp groups and other platforms such as Twitter and Facebook since 2018.
\end{abstract}

Keywords: populism; social media; post-truth; liminarity.

\section{RESUMO}

Há pouco mais ou menos de uma década, o populismo e as redes sociais têm sido questões relevantes, tanto no meio acadêmico como na esfera pública. Neste ponto, os dados de vários países sugerem que a percepção de paralelos entre a dinâmica das redes sociais e a mecânica do discurso populista pode ser mais do que meramente acidental, relacionada a um campo estrutural partilhado. Este artigo sugere um caminho possível para dar sentido à forma como as dinâmicas das redes sociais e a mecânica da mobilização populista têm se coproduzido na última década. Navegando na interface entre a antropologia e a linguística, o texto parte de aspectos chave da noção de liminaridade de Victor Turner para sugerir algumas das formas pelas quais affordances anti-estruturais das mídias sociais podem ajudar a estabelecer uma base para o florescimento contemporâneo do discurso populista: os marcadores da estrutura social são suspensos; a comunitas é formada; o núcleo cultural é

\footnotetext{
* Universidade Federal de Santa Catarina, UFSC, Florianopolis, SC, Brasil. leticia.cesarino@gmail.com Orcid: https://orcid.org/0000-0001-7360-0320
} 
abordado; a mimese e as inversões anti-estruturais são realizadas; os sujeitos tornam-se influenciáveis. Desenvolvo esta afirmação com base em materiais brasileiros, extraídos de etnografia online em grupos pró-Bolsonaro no WhatsApp e em outras plataformas, como Twitter e Facebook, desde 2018.

Palavras-chave: populismo; mídias digitais; pós-verdade; liminaridade

In the past few years, growing concerns about how social media has helped sustain the rise of populist politics around the world have been aired both in academia and in the public sphere. In the aftermath of the Facebook-Cambridge Analytical scandal in 2016, such concerns have evolved into heated debates about regulation and big tech's prevailing business model (DEIBERT, 2019). Indeed, scholarly evidence from multiple countries suggests that perceived parallels between the dynamics of social media and the mechanics of populist discourse may be more than just incidental (SINHA, 2017; MALY, 2018, 2019; MAZZARELLA, 2019; MIROWSKI, 2019; SILVA, 2019; PROCHÁZKA; BLOMMAERT, 2019). While some have understood this relation in terms of "elective affinities" between separate phenomena (GERBAUDO, 2018), others have deemed such resonances co-constitutive enough to warrant their merging on a singular notion, such as algorithmic (MALY, 2018) or digital (CESARINO, 2019) populism. Here I take the latter analytical path to attempt at a contribution towards specifying some of the particular affordances (GIBSON, 1986) and structural features of social media which may be helping co-produce populist politics in Brazil. I will do so by foregrounding the analytical perspective that Gregory Bateson (1967) called cybernetic explanation. Different from the 'positive explanation' common in the social sciences, which looks at cause-and-effect relations between already individuated agents and domains, the 'negative' or 'cybernetic' explanation (BATESON, 1972) takes a step back to look at recursive relations of co-production in a shared field of emerging complexities. While partial and unorthodox, I believe such a systems-theoretical approach may be useful for identifying emerging patterns which may not be immediately visible from an ontic (LACLAU, 2005) perspective focusing on practice and historical contingence. In the Brazilian case, it may help make sense of the deep restructuring of the country's political field that has come about in the past few years mostly through the Internet, and which took many by surprise upon Jair Bolsonaro's meteoric rise to the presidency in 2018.

In this article, my strategy for evincing social media affordances that may be relevant for populist efficacy follows the lead of other anthropologists' recent attempts at making sense of mass society (MAZZARELLA, 2017) and populism (LUHRMANN, 2016) by engaging with classic anthropological theory. Besides 
Marcel Mauss's mana and Mary Douglas's taboo, I believe Victor Turner's liminality and Greogry Bateson's schismogenesis may provide useful insight into the cybernetic-communicational dimension of contemporary populism's reliance on digital media. In what follows, I will elaborate on this point based on Brazilian materials, drawn from online ethnography on public pro-Bolsonaro WhatsApp groups and their broader digital media environment since 2018 .

The first section introduces the Brazilian case by way of a comparison between Bolsonaro and Narendra Modi in India, a pioneer in the deployment of social media for populist mobilization. The parallels found indicate a level of infrastructural commonality despite significant differences in the two countries' historical, cultural and religious backgrounds. The second part zooms in on the Brazilian materials in order to suggest some of the ways in which social media may have helped pave the ground for successful populist mobilization by affording the expansion and dynamic stabilization of a liminal online environment akin to Turner's sense of the term. I conclude by underscoring one aspect of liminality which was not focused on as such by Turner, but which seems key for making sense of contemporary populist efficacy on social media: authenticity.

\section{POPULISM AND SOCIAL MEDIA, IN BRAZIL AND ELSEWHERE}

Reports and analyses of populist leaders who rose to power in their respective countries by mastering social media communication often show striking parallels with the case of Jair Bolsonaro's meteoric rise in Brazil (HALL, GOLDSTEIN, INGRAM, 2016; SINHA, 2017; GERBAUDO, 2018; MALY, 2019). Many such parallels relate to content, involving different forms of nationalism, anti-elitism, anti-secularism, legal and vigilante punitivism. Most often however resonances are structural, suggesting that these political figures' global span might stem at least in part from commonly shared mediations. Likely suspects are neoliberal financialization and the increasingly digitalization of life under way in large swaths of the globe since at least the eighties (BROWN, 2019; MIROWSKI, 2019). The recent rise not just of populist politics but of what has been called post-truth or disinformation are also part of this broader equation (GERBAUDO, 2018; WAISBORD, 2018).

This section outlines some such global resonances not in the abstract, but by way of a comparison between Jair Bolsonaro's digital populist strategy and that of a notable predecessor, India's Prime Minister Narendra Modi. Modi has been a pioneer in instrumentalizing social media for populist mobilization, even 
becoming a successful 'case' for Donald Trump's 2016 chief campaign strategist, Steve Bannon - who is, by the way, close to one of Bolsonaro's sons. Virtually all elements of Modi's political style as Subir Sinha (2017) described it resonate with Bolsonaro's. The two men were local politicians who rose to national prominence as anti-establishment leaders amidst broader anti-corruption movements targeting traditional political parties. In the aftermath of the mass protests that shook Brazil in 2013 and the anti-corruption, pro-impeachment demonstrations that followed in 2015/2016, Bolsonaro's public image slowly evolved from a little-known, fringe Congressman from Rio de Janeiro to aspiring presidential candidate promising to 'drain the swamp' laid bare by Operation Car Wash's anti-corruption crusade.

Along this path, both Modi and Bolsonaro have extensively deployed WhatsApp and other social media in order to bypass mainstream media and the public sphere at large. They did so by actively delegitimizing the professional press and attacking "elite media figures, alleging corruption" (SINHA, 2017, p. 4161). In India, criticism raised by journalists and experts has been dismissed as "paid media" (p. 4161). In Brazil, both during and after the 2018 elections, criticism of Bolsonaro's actions and statements has been explained away in terms of verba (funds): the desperate cry of parasites unwilling to let go of privileges and taxpayer money 'freely' granted to them by the State. Although fundamentally reliant on social media, both Modi and Bolsonaro have selectively engaged with allied mainstream media outlets. In the Brazilian case, a TV channel owned by one of the country's largest evangelical churches, TV Record, has been a faithful government supporter.

In consonance with the basics of populist mechanics exposed by Ernesto Laclau (2005), both leaders' discourses (and the memetics supporting it) simplify and split the social field into two distinct, friend-enemy camps, which feed off each other through escalating opposition, or schismogenesis. Like Donald Trump (HALL; GOLDSTEIN ; INGRAM, 2016), they have done so by deploying funny, "low", and/or "highly emotional, slogan-based language and a 'verbal radicalism combined with political marketing skills"' (SINHA, 2017, p. 4160), and by decrying expert, formal language as "boring", "too serious" and distant from the realities of common folks. In both cases, memetics spreads narratives "of decline and crisis, the backdrop against which the leader emerges to take the people out" (p. 4167). Teams Modi and Bolsonaro act online in highly coordinated fashion, particularly for "hit and run" takedowns of opponents using similar or even identical language and procedures (p. 4172). 
The two leaders are also exemplary of the centrality of legal punitivism in the current neoliberal formation (COMAROFF; COMAROFF, 2004). Both appeal widely to vague notions of "law and order" and vigilante-style justice, while decrying human rights and belittling the due legal process. At the same time, they dismiss grassroots social policies (such as the Bolsa Família, Brazil's chief cash transfer policy to poor families) as "'povertarian' sops-for-votes", and actively discourage worker unionization (p. 4162). Their preferred constituency is a rising entrepreneurial "neo-middle class" eager to displace old economic-political elites, such as the large contractors targeted by Operation Car Wash in Brazil. Their discourse is at the same time socially conservative, and economically liberal (BROWN, 2019).

Sinha (2017) also remarks how, in India, the dynamics of social media stabilizes a feedback loop between leader and people, who come to be simultaneously and dynamically co-constituted by their reciprocal relations. Like with Bolsonaro, "several themes and terms used by Modi in his campaign speeches were crowdsourced, based on comments and suggestions collated from ... social media" (p. 4165). Both leaders regularly interact with supporters through their personal profiles on social media and live chats - Modi on YouTube and Google+, Bolsonaro on Facebook. Like "the king's digital body" in Brazil (CESARINO, 2020a, 2020b), Modi's construction of the people has also involved a high degree of fractalization, or what Sinha (2017) described as molecularization: "it retained an element of central control while enabling more decentralized practices of constructing a people" (p. 4167). And like Bolsonaro did with world-renowned Brazilian educator Paulo Freire (author of Pedagogy of the Oppressed) and virtually the entire post-dictatorship political spectrum, Modi desecrated long-standing national figures in India such as Nehru and the Ghandis, and their Congress Party.

The two leaders are, moreover, fixated on rewriting history from the point of view of their respective 'revolutions'. Both offer an "alternative narrative of nationalism and postcoloniality" which turn previously hegemonic histories inside out. While Modi's focus is on the anti-Muslim Hindutva, Bolsonaro's effort has been to redeem painful periods of Brazilian history, such as the 19th century monarchy (marked by slavery and the crushing of regional insurrections) and especially the Military Regime (1964-1984). They have done so based on "unsubstantiated allegations" which eventually become "self-evident facts" upon being widely circulated online (SINHA, 2017, p. 4168). Both leaders eschew liberal pluralism, and equate the nation with their own group: while Bolsonaro's supporters exhort leftists to "go to Venezuela" or "to Cuba", Modi's followers tell their enemies and critics to "go to Pakistan" (p. 4169). Modi and Bolsonaro posit 
themselves as "true' democrats representing a pure people's sovereignty" (4160). By reducing democracy to popular sovereignty and majority rule, and ignoring or outright attacking institutionalist-liberal principles such as the balance of powers and minority rights, both leaders are reshaping the very meaning of democracy, truth, and the public sphere in their countries.

Of course, there are numerous differences in context and content between Bolsonaro, Modi, and other right-wing populist leaders globally. Yet, these sharp differences only make the similarities between them the more striking and potentially more fundamental. In what follows, I will claim that these and other common patterns may stem at least in part from a shared infrastructure, anchored on social media platforms now widely available globally through cheaper and increasingly more popular smartphones. I will do so by suggesting how particular structural features of contemporary digital media may afford a liminal space that potentializes the efficacy and capillarity of populist-style political mobilization.

\section{CRISIS AND LIMINALITY}

British anthropologist Victor Turner originally developed his theory of liminality as part of a structural-functionalist explanation for the performative efficacy of tribal rituals. The same notion was eventually extended by Turner himself to anti-structural movements in Western societies, such as the hippie counterculture or Christian pilgrimage, which he framed in terms of an exceptional social form he called communitas. Turner's inspiration came from early twentieth-century French folklorist Arnold Van Gennep's three-stage scheme for rites depassage: separation (from regular social structure), an intermediary stage he called limen ('threshold' in Latin), and reaggregation. Comparing his own long-term fieldwork with the the Ndembo of Zambia with ethnographic findings by other anthropologists worldwide, Turner identified a few structural traits of the liminal condition that resonate with some of my research findings about how pro-Bolsonaro digital networks were formed and maintained..

It has been widely recognized that populist rupture is more likely to take hold in contexts of widespread dissatisfaction, when originally disconnected antiestablishment demands and identities are brought together in a common chain of equivalence by a charismatic leader claiming to speak from outside the system (LACLAU, 2005; GERBAUDO, 2018; MAZZARELLA, 2019). The efficacy of populist mobilization is in this sense predicated on a break with some previouslyexisting hegemonic structure - or, in Kuhnian terms (KUHN, 1970), it may be a 
sign of the latter's exhaustion. It is my hypothesis that the massive 2013 protests in Brazil, a reverberation of the Arab Spring wave set off a few years earlier, opened the path to a liminal period in the country's political field which lasts to this day. At that moment, hitherto prevalent political structures based on the Workers' PartySocial Democratic Party polarization were suspended, and anti-structural forces sprang to surface, pressing for sharp and deep rearrangement of the political field, including long-held assumptions about the left-right spectrum. It was then that the so-called 'new right' erupted from the Internet on to the broader public sphere as a major force in the struggle for redefining not just political content, but the grammar of democratic politics itself.

Five years intervened between the 2013 break and Bolsonaro's rise to the presidency in 2018. During that period, the highly heterogeneous, diffused street protests were gradually displaced by a more cohesive anti-corruption, anti-Workers' Party movement in the aftermath of Operation Car Wash. Popular dissatisfaction and anti-establishment sentiment persisted even after Rousseff was impeached in 2016. Her vice-president Michel Temer carried on a highly unpopular administration until the 2018 elections. Until then, Bolsonaro was known less for a concern with corruption than for a punitivist crusade against political correctness and human rights' supposed protection of crooks and criminals. Beginning in 2016, he gradually rose to the national stage as aspiring presidential candidate by taking advantage of the antagonistic structure pitting corrupt elites against righteous citizens (cidadãos de bem) championed by Judge Sergio Moro and the Public Prosecutors who jailed former president Lula and many others in the Workers' Party (ANSELL, 2018). The figure of the 'socialist' enemy, which would eventually conflate with others such as the street criminal and child molester, became key to Bolsonaro's online campaign and victory in the 2018 elections (EVANGELISTA; BRUNO, 2019, CESARINO, 2020).

The elections therefore took place in a context of high dissatisfaction and widespread sentiment of chronic crisis - political, legal, economic, moral, ethical among broad swaths of the population. I have suggested (CESARINO, 2020b) that this may have been in part reinforced by social media itself, saturated with punitivist and moralizing content about the social fabric being disrupted by particular groups (urban criminals, Workers Party's corrupt politicians, identity politics) portrayed as inherently bad. In this sense, Bolsonaro's rise fed on what Jean and John Comaroff (2004) called a "metaphysics of production and reduction of disorder": social media spread a sense of epistemic and moral crisis and disorganization, while at the same time offering a reductionist, populist-style solution for remaking a corrupt society anew by the hands of an all-powerful, untainted anti-establishment outsider. 
Recent debates about hybrid war, memetic warfare and psy-ops techniques applied to political marketing indicate that a chaotic, liminal-like environment may be proactively produced on and through digital media by populist-style politics and alt-right groups (DAVIES, 2018; WALL; MITEW, 2018; MIROWSKI, 2019). Elsewhere (CESARINO, 2020b) I made a similar suggestion about how the Bolsonarist mechanics succeeded in stabilizing political schismogenesis on and through social media. While in the Melanesian context where it was originally identified by Bateson (1958) schismogenic opposition would lead to some kind of resolution, being it alleviation of tension or schism between the opposing parties, in contemporary digital populism escalating oppositional patterns are sustained online without meeting a definite resolution. Social media's scalable sociality (MILLER et al., 2016) affords the formation of closed echo chambers which feeds recursively on the adversaries' oppositional actions.

In what follows, I elaborate further on the hypothesis that 2013 opened up a liminal period sustained by social media, which became an environment fertile for antistructural politics, or populism. Bolsonaro's hegemony-building strategy gained ground slowly, gradually enlisting different segments of the population, from an original core of devoted fans to more intensive mobilization on WhatsApp in order to quickly build an electoral majority on late 2018 (EVANGELISTA; BRUNO, 2019; CESARINO, 2019B, 2020b). I suggest some of the ways in which, especially as the 2018 elections approached, certain affordances of social media, WhatsApp in particular, may have helped sustain a liminal environment conducive to populist-style mobilization (LACLAU, 2005). I do so by moving back and forth between my empirical materials and Turner's original ethnographic data and theorization on liminality. My intention however is not to take liminality only as a useful metaphor. My sense is that what Turner objectified as liminality (WAGNER, 1975) among the Ndembo points at that which comes to the fore when regular social and individual life is upended by some break, and a new, stable configuration has not yet emerged. In this interregnum, as Antonio Gramsci famously put it, a great variety of morbid symptoms may appear.

\section{HOW SOCIAL MEDIA AFFORDS LIMINALITY}

\subsection{Markers of social structure are suspended}

According to Turner (1969), the first effect of the liminal stage on Ndembo initiands is to remove preexisting markers of social structure: "secular distinctions of rank and status disappear or are homogenized" (p. 360), leaving "nothing that 
may distinguish them from their fellow neophytes" (p. 359). Based on a comparison with ethnographies about ritual in other societies, he noted that a "recurrent theme in liminal situations" is "the stripping off of preliminal and postliminal attributes" (p. 364). In tribal rituals, this imperative often translates as nakedness, or homogenizing esthetics and attire.

In their analysis of pro-Trump conspiratory memetics, Procházka and Blommaert (2019, p. 35) noted how (relative or absolute) online anonymity often removes "sociological diacritics" of "gender, age, even nationality or place of residence", leaving the analyst only with social action and the semiotics of online interactions. But what may be a problem for those aiming at a sociological analysis is precious data from a structural perspective. In large online public groups, such as those formed on WhatsApp during the 2018 campaign in Brazil, this is often how users see each other: as deprived of their original "sociological diacritics". Stripped of visible signs of particularity, users are ready to be enlisted into an emerging chain of equivalence connecting all of them anew and around the centralizing figure of the leader (LACLAU, 2005).

Also according to Turner (1967), during the liminal stage Ndembo neophytes are "reduced or ground down to a uniform condition to be fashioned anew" (p. 359). In my online experience with Bolsonaro followers, the suspension of conventional social markers affords an environment prone to the emergence of new identities. Identities formed online through social media profiles are both highly individualistic and highly relational. While platforms allow for only one, well-bounded individual profile at a time, every profile is continuously co-produced through feedback loops with other user profiles. If such networked engagement disappears, the online persona ceases to exist as such. Even though WhatsApp was not meant to be a social media platform, it comes to operate largely as one in contexts like Brazil's, where interactions between users are often articulated through large public groups within a broader social media environment (Facebook, Twitter, YouTube, alternative media websites).

A remarkable manifestation of the performative power of social media to remake political identities is the fact that, before 2013, "conservative" was not a common self-assigned political identity in Brazil, and the meaning of being "rightwing" resonated more with what Bolsonaro supporters would today call "old politics". The new right (which, among themselves, is referred to as just "the right") has set a new bar for the political spectrum in Brazil. These rearrangements are not born out of thin air: the new right memetics circulating online diffuses an extensive pedagogy showing users what it means to be right-wing or conservative, often in 
opposition to what they resignify as being "the left" according to the same general framings for the enemy. More recently, dissidents of Bolsonarism have been called the "new left". The sense of phoenix-like rebirth in pro-Bolsonaro groups in the aftermath of his electoral victory was indeed astounding: voters expected Brazil to be fully remade "under new management", as some memes put it.

These are not just categorical rearrangements taking place on people's minds; they are embedded in intense reshaping of sociabilities and affect-based group belonging. According to Turner (1967), in liminality neophytes develop "intense comradeship and egalitarianism" (p. 359-60). During the campaign, Bolsonaro supporters would refer to each other through terms not commonly applied to party politics, such as patriotas (patriots) or the Army interjection Selva! (woods). Female supporters would call each other by neologisms such as bolsogatas or bolsolindas (bolso-beautiful). In the most radical iterations of boundary-making, those outside the group were accordingly characterized as nasty, repulsive, and treacherous not adversaries with whom to engage through rational dialogue, or democratically tolerated, but enemies to be expelled or even eliminated (MOUFFE, 2000). Whenever online opposition overflowed to street demonstrations, group members were indeed leveled out, all in green-and-yellow uniform, sometimes performing synchronic chants and choreographies created especially for the campaign by voters themselves, which circulated widely in video form on Whatsapp and social media platforms.

WhatsApp or Facebook groups, or filter-bubbles on Twitter and elsewhere, are in this sense functionally analogous to the bush huts built for Ndembo initiands, where they were kept isolated from regular village life until the liminal stage was completed and they were ready for reintegration into society at large. A difference here is that, in digital populism, reintegration is not in sight. Much to the contrary, the whole apparatus is put in place in order to keep users sealed off from the broader public sphere - or to purposely fragment the latter into a camp of truth and authenticity opposed to a threatening outside made up of lies, hypocrisy, and conspiracies. Gatekeeping here is active, and may range from human (individual or collective) curators such as influencers and groups admins, to nonhuman conscripts like bots, platform algorithms, or, on WhatsApp, peer-to-peer cryptography. Whatever proposal to control or regulate online misinformation is denounced as censorship and encroaching on the freedom of speech. In this sense, the Bolsonarist digital sphere approximates Kelty's notion of recursive publics, that is, a group constituted online by means of a reflexive "concern for the technical and legal conditions of possibility for their own association" (KELTY, 2005, p. 185). 
Common users thus find in pro-Bolsonaro closed networks a safe space sealed off from external interference and oppositional claims. Group borders on WhatsApp and Facebook are constantly policed by rigid rules ("no leftist / communists allowed"), expulsion of undercover spies or traitors by group admins, and general suspicion of whoever criticizes the president or shows an alternative vision of what it means to be right-wing or conservative. This pattern intensified in the post-electoral period: in retrospect, the WhatsApp groups which I joined during the electoral campaign seemed more diverse than those consolidated after Bolsonaro took office. As others also remarked (NEMER, 2019), these groups tended to become increasingly closed and radicalized, around calls for military intervention or religious (particularly evangelical Christian) demands. Within these newly carved spaces, Bolsonaro supporters have reshaped their personal identities along the lines of "emerging communities" (PROCHÁZKA BLOMMAERT, 2019, p. 35) which resemble in many ways Turner's communitas.

\subsection{Communitas is formed}

As Turner (1969) described it, liminality is based on an anti-structural social form he called communitas: "society as an unstructured or rudimentarily structured and relatively undifferentiated comitatus, community, or even communion of equal individuals" (p. 360). In this kind of liminal formation, even temporality works differently than in regular social structure:

\footnotetext{
We are presented, in such rites, with a moment 'in and out of time', and in and out of secular social structure, which reveals, however fleetingly, some recognition (in symbol if not always in language) of a generalized social bond that has ceased to be and has simultaneously yet to be fragmented into a multiplicity of structural ties (p. 360).
}

In the context of digital populism, communitas ties operate analogously to Laclau's chain of equivalence, which brings and binds individuals together by selecting out particularities in favor of shared, vague signifiers incorporated in the person of the leader and the body politic. In populism at large, the chain is extended by means of empty signifiers indexing some kind of "generalized social bond", often involving vague notions of nationhood. In the case in point, "paramount symbols" (TURNER, 1970) exhaustively explored in the Bolsonarist memetics included the Brazilian anthem and flag, its yellow-and-green colors, references to the Army, and, crucially, the national soccer team shirt - probably the most widespread and capillary symbolic and affective form of attachment between Brazilians and the nation. These were all regularly contrasted with signifiers of the enemy, such as 
the Workers' Party's symbols, communist flags, and their red color (CESARINO, 2020b).

Triggers commonly deployed for spreading (mis)information online "Attention!", "Beware!", "Urgent!" - contributed to extending the chain of equivalence and communitas particularly inside and between WhatsApp groups, as well as on YouTube. On platforms such as Twitter, this connective function was, and still is, largely performed by hashtags figuring empty signifiers which are regularly created and spread by influencers, bots and common users to address every emerging issue or controversy around the government. It is not uncommon to have a schismogenic counterpart to it on the left, in the form of symmetric inversions such as "NotHim" versus "YesHim", or "WhoOrderedMariellesMurder" versus "WhoOrderedBolsonarosMurder".

Social media therefore afford what Mazzarella (2018) and others consider to be the core of populism: a kind of mediation that produces a paradoxical effect of non-mediation between leader and people. In Brazil, such effect was evident in the expectation shown by many Bolsonaro supporters that it is possible to access him directly: with enough luck, a common user's message on WhatsApp or Twitter may go viral and travel all the way to Jair's personal smartphone. "Please share until it reaches the president" is a common trigger in pro-Bolsonaro networks. The president himself makes sure to regularly feed such expectation, for instance by tweeting that a particular official decision was taken after hearing a request by some social media follower.

Communitas may be also regarded as an effect of the digital format itself, which affords fractalizing the populist mechanics into what I called "the king's digital body" in the aftermath of the September $6^{\text {th }}$ knife attack (CESARINO, 2019a, b). If, as Mazzarella (2018) remarked, populism is predicated on the "radical fullness of the body of a leader in which the people may find a palpable image of their own substance" (p. 52), the removal of Bolsonaro's ailing body from the public sphere led to its replacement with a sprawling digital body formed by his supporters, who took over the campaign on his behalf. Especially after accusations of illegal bulk-messaging on WhatsApp were raised by the press, they began to self-identify as "Jair's marketers", a signifier which eventually fluctuated as "Jair's electoral inspectors", "Jair's shield", "Jair's army", or "Bolsonaro's robots".

The knife attack thus took to an extreme the fractalizing potency of the digital. As Coronil and Skurski (1991) argued, violence

pushes the limits of the permissible, opening up spaces where customary and unexpected meanings and practices are brought together in unprecedented ways, illuminating hidden 
historical landscapes in a flash... the territoriality of nations and the corporeality of people become privileged mediums for reorganizing the body politic ... Individual biography and collective history seem momentarily united, as history and the body become each other's terrains (p. 290).

\section{Like the populist leader, the Ndembo paramount chief}

represents both the apex of the structured politico-legal hierarchy and the total community as an unstructured unit. He is, symbolically, also the tribal territory itself and all its resources. Its fertility and freedom from drought, famine, disease, and insect plagues are bound up with his office, and with both his physical and moral condition. (TURNER, 1969, p. 361)

The knife attack consummated a process whereby the leader's body and the body politic became each other's metaphors: the body (Bolsonaro, Brazil) is hurt and under attack (by leftist militancy; by corruption); union and action are necessary in order to defend it from a common enemy. At the time, memes circulated widely showing reproductions of the T-shirt Bolsonaro was wearing during the stabbing: the point where the knife pierced his stomach soaked in deep red blood (the color of the enemy), precisely next to (and in sharp contrast with) the yellow-and-green word Brazil. The T-shirt read: "Brazil is my party". For his most pious followers, from then on Bolsonaro's individual well-being became conflated with the nation's destiny. Prophetic versions of the event ventilated online by evangelical pastors made sure to add a powerful theopolitical framing to it.

\subsection{The culture core is addressed}

According to Turner (1969), communitas is about "giving recognition to an essential and generic human bond, without which there could be no society". Symbols ritually mobilized during the liminal stage often address essentials and fundamentals of local ontologies - what Turner called their culture core. These included objects and words symbolizing "the historical unity of the Ndembo people", the multiple villages' common origin in mythical time, "the land ... and the total community living on it". Their invocation aimed at "fertility and continued health and strength of the land ... and the people" (p. 361).

Analogies with widespread populist summoning of nationhood and its core symbols are evident here. Also in Bolsonaro's case, national symbology is omnipresent in the full spectrum of memetics aimed at producing equivalence between the leader and people (CESARINO, 2020b). Nationalist signifiers such as the flag, the colors green and yellow, the national anthem, the soccer shirt, the coat of arms were extensively deployed in order to mobilize elementary notions of order, 
control, security, and corresponding affects of love, hope, and justice. Even today, Bolsonaro supporters on Twitter and WhatsApp regularly display the Brazilian flag in their profile description (sometimes accompanied with those of the U.S. and Israel), while their left-leaned opponents tend to prefer red flags or flowers. These icons allow for quick and easy identification of political camps, further contributing to the dichotomous polarization that marked the electoral campaign and persisted into Bolsonaro's government.

As was suggested above, patriotism is at the core of Bolsonaro supporters' common identity. It is not about representation, but rather experienced as direct, unmediated expression of the nation's culture core: popular sovereignty. Widespread mottos encapsulate the notion that such belonging refers to a more fundamental domain, beyond (or before) regular political structure: from the official campaign slogan 'Brazil above everything; God above everyone' to catchphrases like 'The left does activism. The right does patriotism.' During liminality, identity is about more-than-human powers: "a mystical character is assigned to the sentiment of humankindness" (TURNER, 1969, p. 365). It is a moment of fragility but also of empowerment, when initiands are "endowed with additional powers to enable them to cope with their new station at life" (p. 359). Esthetical patterns widespread in pro-Bolsonaro networks display montages of the president and other charismatic personalities such as Judge Sergio Moro merged with heroic figures like superheroes, soldiers, medieval crusaders, and even sided with Jesus Christ and other biblical figures. Many Bolsonaro followers act online as if they were indeed on a Marvel movie, or amidst a decisive, even mystical or messianic battle for the future of Brazil.

This is not about representation in conventional politico-institutional terms, but about its opposite: fully-fledged authenticity. There is supposed to be nothing behind or beyond Bolsonaro and his followers' love for the motherland, their embodiment of the people's will. Whoever is perceived as representing something else - political interest, personal gain, occult conspiracies - is promptly excluded from the group. By rendering the mediations that perform such identities and attitudes invisible (ENLI, 2015), social media afford the expectation of direct and full equivalence between voters, leader, and the source of all power: the people, the nation, God itself.

\subsection{Mimesis and anti-structural inversions are performed}

During the fifties and sixties, Turner and other members of the Manchester School of Anthropology elaborated extensively on a recurrent feature of rituals and 
liminal moments in different societies: structural inversions. What Max Gluckman (1954) called rituals of rebellion focused on one aspect of liminality whereby social tensions which are normally suffocated can be openly expressed, thus allowing the social structure to be periodically renewed without sharp revolutionary breaks. For the Ndembo, Turner recorded liminal inversions where "the underling comes uppermost", and "the supreme political authority is portrayed as 'a slave" (1969, p. 364). Travestism inverting gender roles was also found in many rituals, from Gluckman's work with several South African peoples to Bateson's kaleidoscopic account of the Melanesian naven (BATESON, 1958). Brazilian anthropologists and Turner himself elaborated on the Brazilian Carnival as an exemplary inversion ritual, where low qualification workers become kings and queens, and their bosses move to the peripheral position of the audience (DA MATTA, 1991).

Comparing Ndembo rituals with those of other tribal societies, Turner put forth a general argument about

a certain homology between the "weakness" and "passivity" of liminality in diachronic transitions between states and statuses, and the "structural" or synchronic inferiority of certain personae, groups, and social categories in political, legal, and economic systems. The "liminal" and the "inferior" conditions are often associated with ritual powers and with the total community seen as undifferentiated (p. 362).

Turner's claim that, in liminality, "lowliness and sacredness" are conflated resonates strongly with Mary Douglas' classic argument about taboo also put forth in the sixties. Tanya Luhrmann sought inspiration in Douglas to make a peculiar claim about Trump's rise as the taboo turned sacred. As the pangolin, paramount taboo animal among the African Lele,

The populist politician is the 'impolite guest' at the civic dinner party; his or her charisma thus has less to do with any specific political content than with the sheer fascination of 'the element that 'falls out' of the gentrified system"" (MAZZARELLA, 2019: 51).

In this sense, Trump's election, like Bolsonaro's, may be regarded as a call for restituting order by means of radical inversion only possible at a liminal moment, when regular structures are suspended. A taboo element is then elevated to holy being, the one capable of purifying a corrupt system and reconstituting the integrity of the group (in this case, the Brazilian nation) on radically new foundations: "That which is rejected is ploughed back for the renewal of life" (DOUGLAS, 2002, p. 121).

In Brazil, the populist narrative of inversion (LACLAU, 2005) found a powerful Christian Evangelical version. For those who read political conjuncture 
through messianic lenses, the knife attack was a prophetic sign that Bolsonaro had been sent by God in order to purify Brazil. In a popular video that circulated online just before the polls, Pastor Silas Malafaia evoked the following passage from the book of Corinthians during a preaching with Bolsonaro:

God chose the foolish things of the world to shame the wise; God chose the weak things of the world to shame the strong. God chose the lowly things of this world and the despised things — and the things that are not — to nullify the things that are.

He then pointed at Bolsonaro's chest, declaring: "and that's why God has chosen you". The left circulated it as a hilarious video, but in fact Malafaia's is a language to which many Brazilians can relate, for they are indeed the despised, the weak, the lowly things of this world. Whenever Bolsonaro was accused of being ill-qualified to the position of president, he would not deny the accusations, but capitalize on them by retorting that "God does not choose the qualified, $\mathrm{He}$ qualifies the chosen". That powerful statement reads like a fully-fledged theological version of the radical populist inversion described by Laclau (2005), when structure is not just suspended, but fully turned inside out.

In the memetics circulated online during the electoral campaign, such inversions were frequently performed through mimetic language. It is indeed remarkable the extent to which the two interrelated discursive axes that Laclau (2005) described as the core of populism - internally-directed syntagmatic relations (which constructs equivalence within the group) and externally-directed paradigmatic opposition (which constructs difference in relation to a constitutive outside) - operated through mimesis. Internally to the group, mimetic language sought to perform "tight if not perfect identity: mimesis without remainder" (LEMPERT, 2014, p. 382), that is, full equivalence between leader and people. Externally, "inverse aesthetic seeks divergence, at times producing ironically parallel, mirror-image symmetries like coconstitutive pairs in which each seems a foil for the other" (LEMPERT, 2014, p 382).

Elsewhere (CESARINO, 2019b, 2020b), I brought multiple examples of such inversions in the pro-Bolsonaro memetics, where signifiers in the Bolsonarist camp are constructed as inverted mirrors of those on "the left". Anti-feminist memetics for instance would often cannibalize their enemy's slogans: "fight like a girl - a true [that is, right-wing] girl". The Bolsonaro face logo deployed the same design of Che Guevara's classic branding. When The Intercept published leaked Telegram messages exchanged between Judge Moro and federal prosecutors during Operation Car Wash, an anonymous profile was immediately created on Twitter exposing fake print screens of 'leaked' messages among The Intercept journalists. Memes 
elaborating on the knife attack often mirrored an online campaign championed by the left to press for investigating Rio Councilwoman Marielle Franco's murder on March 2018: "28 days without an answer. Who killed Marielle?" became "Who ordered Bolsonaro's murder? 33 days without an answer". Jair Bolsonaro is himself an almost perfect inversion of Marielle Franco's female, black, lesbian, young, activist, intellectual, peripheral body.

The new right's emerging grammar seems to be deeply embedded in such mimetic practices, including in relation to one of its foremost enemies, identity politics (Nagle, 2017). Bolsonaro's populist style is in many ways a copy of Donald Trump's: from the habit of trolling enemies by giving them nicknames, to gestural enactments such as the hand pistol symbol, to "comedic entertainment to attract media attention - no matter how negative that media attention may be" (HALL; GOLDSTEIN; INGRAM, 2016, p. 75). Broadly speaking, however, mimesis is part and parcel of social media itself: the digital format is fundamentally a technology of fast and easy copying. It is disruptive by design.

In the contemporary regime of post-truth (HARSIN, 2015), truths are produced and diffused through mimetic citationality, rather than the tradition-like structure (KUHN, 1970) or organized neguentropic circuit based on controlled inscription chains Latour and Woolgar (1986) described for scientific knowledge. On social media, catchphrases, images, logos, slogans circulate fast, with no reference to an original source. Ambiguity is part and parcel of its performative efficacy. Those in the Bolsonarist camp play extensively with the kind of increased entropy and equiprobability that digital media affords (CESARINO, 2020a). Impossibility to discern between irony and sincerity, a joke and a serious statement, fake and authentic content allows populists such as Trump and Bolsonaro wide scope for tactical reversals, withdrawals and "easy deniability" (HALL; GOLDSTEIN, INGRAM, 2016, p. 74) whenever the situation requires it. Yet such entropic environment was not created by the populists; it is a structural feature of the contemporary Internet and its prevailing business model (MIROWSKI, 2019).

As Blommaert (2018) suggested for Trump's tweets, the populist leader's online language is meant to be mimicked and replicated: "they contain lots of pointers as to exactly how they can be delivered in spoken speech. In other words, they are instructional, showing his followers how to speak like Trump". As such, they are meant "not just for contemplation and admiration by his audience, but for active uptake and repeated offline performance" (p. 5). While this is also true for Bolsonaro's tweets and other online behavior, it can be even extended beyond himself, to the full memetic grammar circulating on the Bolsosphere. As a result, 
in platforms such as Twitter and Facebook it has become increasingly difficult to differentiate individual from collective, authentic from automated, human from nonhuman language and behavior. Like populist politics itself, the current architecture of social media complicates and challenges previously-held assumptions about agency and individuality, spontaneity and manipulation, freedom and control. In this sense it sustains a liminal environment where language becomes highly mimetic and performative.

\subsection{Subjects become influenceable}

Turner remarked on how, in communitas, individuals are stripped of structural markers and turned equal in order "to submit to an authority that is nothing less than that of the total community" (1969, p. 364). During ritual, this kind of deep pedagogy must involve total surrender: "The neophyte in liminality must be a tabula rasa, a blank slate, on which is inscribed the knowledge and wisdom of the group, in those respects that pertain to the new status" (p. 364). The individuals' behavior must be "passive and humble; they must obey their instructors implicitly, and accept arbitrary punishment without complaint" (p. 359). He listed foolishness, simplicity and heteronomy (as opposed to autonomy) among the individual attitudes expected during liminal moments. These however must not be read as moral indictments, but as structural dispositions enabled by the ritual environment, prerequisites for farreaching change in status. Status change is carried out under the guidance of an official, to which individuals must fully submit and trust.

Many parallels may be drawn to enlistment in sect-like organizations, and indeed such comparisons have been made for the Bolsonaro family's ideological guru, Olavo de Carvalho, by former followers and even his own daughter. Here however I will limit my focus to one fundamental structural feature of big tech's prevailing business model: "the behavioral vision that has informed the design of social media architectures and encourages a conception of users as influenceable subjects, not knowledge agents" (Marres 2018: 435). As Marres put it, social media is a "truthless public sphere by design" that works precisely by "doing without interpretation". Its design is guided by principles inspired less in the social sciences than in the dynamics of "viral contagion or the flocking of birds", which are predicated on "the 'manipulability' of users" (435) in order to work. Users' identities and desires are recursively shaped by algorithmic mediations which associate them with others through homophilic networking, thus further promoting echo chambers and confirmation bias. 
Marres' diagnostic is strikingly resonant with Philip Mirowski's cybernetic view on neoliberalism as an epistemic doctrine. His reading of the neoliberal thought collective's metaphysical foundations unveils "an image of humankind as rather slovenly and undependable cognitive agents", the "necessary compost out of which a spontaneous order might blossom" (MIROWSKI, 2019, p. 6). Such order would come about by thinning planning agencies such as the state, policy experts and public education, and submitting individual will to "the market" as "an information processor more powerful and more efficacious than any human being was or could ever be" (p. 6). As this author put it, the neoliberals did not plan or invent the Internet, but it was their "greatest gift". The business model which has shaped social media as we know it today has recursively helped perform the very principle of influenceability that is at the core of both populist politics and the contemporary post-truth regime.

\section{CONCLUSION: ON AUTHENTICITY AND SPONTANEITY}

In his accounts of Ndembo rites of passage, Turner often remarked the centrality of symbols of non-mediation between individuals and primordial, out-ofstructure domains, such as the firewood which "must not be cut by an ax but found lying on the ground. This means that it is the product of the earth itself and not an artifact" (Turner, 1969: 362). In other words, when mediations embedded in regular social structures are withdrawn or suspended during liminality, direct access to a "really real" comes to the fore as a possibility or an expectation.

Edward Sapir's 1923 essay on "Culture: genuine and spurious" may be read as a structural theory of authenticity. From this perspective, what he means by genuine (or authentic) culture appears as a pattern of mediations that are wellaligned across different scales - individual and group; material and spiritual life; and across multiple social domains (religious, economic, political, domestic, and so forth). Individual and collectivity seem to be fully lined up, to a point of collapsing differences of scale between them: in an ideally authentic culture, as Sapir put it, "culture is internal" to the individual. It might be this sense of fullness, of unity, that seems to be lacking in our increasingly financialized and digitalized societies, and may be the root of the growing nihilism that Wendy Brown (2019) and others have recently identified as a prominent feature of our times. That might indeed be what many are looking for in populist charismatic nationalists like Jair Bolsonaro or Donald Trump. Contemporary obsession with authenticity and spontaneity in politics may reflect broader anxieties about mediations in a post-truth condition 
where expert systems and other established sources of social trust (such as the legal or political-representative system) are regarded with increasing suspicion by the general public (GRAAN, HODGES; STALCUP, 2020).

As media scholars have shown, authenticity - which Enli (2015) disaggregates into trustworthiness, originality and spontaneity - is a major key to efficacy in contemporary social media. Indeed, it is the original source of Bolsonaro's charisma as a honest, even if uncouth, man with no fear of speaking his mind against 'power', especially political correctness. Bolsonaro's online influence has been largely bolstered by performances of rehearsed spontaneity and infrastructural precarity: photos taken at his home on a messy breakfast table, while playing videogames, wearing pajamas and flip-flops, or recording Facebook lives while getting his hair cut. Accordingly, like in the MAGA kid incident analyzed by Procházaka and Blommaert (2019), counter-attacking enemies quite often means questioning their spontaneity and authenticity: Bolsonaro's main opponent in the elections was former President Lula's marmita (packed lunch); Greta Thunberg has her speeches written by grown-ups; the head of Brazil's spatial research institute rang the alarm for the Amazon fires because he must be working for some foreign NGO.

As Wendy Brown (2019) recently stressed, spontaneity has been also a key assumption for the original neoliberal doctrine: Hayek dreamed up not just of markets but of traditional morality as spontaneous organizers of his ideal free society. He assumed traditional morality sprang from organically articulated norms embedded in individuals and families, spontaneously, from the bottom up. Fascism involves a similar kind of organicism, but imposed from above, by an authoritarian leader or party. Of course, Hayek and the pioneer neoliberals strongly opposed the fascism of their time. When seen from a structural perspective, however, the clear-cut opposition between the two depends on having clear discernment between what is spontaneity and what is manipulation; what is authentic, and what is spurious; what is bottom, and what is up. The current architecture of the Internet, by casting us into a paradoxical form of enduring liminality, has deeply complicated our capacity to distinguish between these. This could be a crucial nexus between the contemporary digital revolution and the spread of authoritarian populism in Brazil and elsewhere.

\section{REFERENCES}

ANSELL, Aaron. (2018) Impeaching Dilma Rousseff: the double life of corruption allegations on Brazil's political right. Culture, Theory and Critique. v. 59, pp. 312-331. 
BATESON, Gregory. (1958) Naven: A Survey of the Problems suggested by a Composite Picture of the Culture of a New Guinea Tribe drawn from Three Points of View. Stanford: Stanford University Press.

BROWN, Wendy. (2019) In the ruins of neoliberalism: the rise of antidemocratic politics in the West. Nova Iorque: Columbia University Press.

CESARINO, Letícia. (2019a) On digital populism in Brazil. Political and Legal Antbropology Review - Etbnograpbic Explainers. Available at: https://polarjournal.org/2019/04/15/onjair-bolsonaros-digital-populism/

CESARINO, Letícia. (2019b) Identidade e representação no bolsonarismo: corpo digital do rei, bivalência conservadorismo-neoliberalismo e pessoa fractal. Revista de Antropologia. v. 62 , n. 3 , pp. 530-557.

CESARINO, Letícia. (2020a) What the Brazilian 2018 elections tell us about post-truth in the neoliberal-digital era. Cultural Antbropology - Hot spots. Available at: https://culanth. org/fieldsights/what-the-brazilian-2018-elections-tell-us-about-post-truth-in-theneoliberal-digital-era

CESARINO, Letícia. (2020b) Como vencer uma eleição sem sair de casa: a ascensão do populismo digital no Brasil. Internet \& Sociedade. v. 1, n. 1, pp. 91-120.

COMAROFF, Jean; COMAROFF, John. (2004) Criminal obsessions, after Foucault: postcoloniality, policing, and the metaphysics of disorder. Critical Inquiry. v. 30, n. 4, pp. 800-824.

DAMATTA, Roberto. (1991) Carnivals, Rogues, and Heroes: An Interpretation of the Brazilian Dilemma. Notre Dame: University of Notre Dame Press.

DAVIES, Will. (2018) Nervous States: How Feeling Took Over the World. London: Jonathan Cape, 2018.

DEIBERT, Ronald J. (2019) The Road to Digital Unfreedom: Three Painful Truths About Social Media. Journal of Democracy. v. 30, n. 1, pp. 25-39.

DOUGLAS, Mary. (1966) Purity and danger: an analysis of concepts of pollution and taboo. New York: Routledge.

ENLI, Gunn. (2015) Mediated Authenticity: How the Media Constructs Reality. New York: Peter Lang. 
EVANGELISTA, Rafael; BRUNO, Fernanda (2019) WhatsApp and political instability in Brazil: targeted messages and political radicalization. Internet Policy Review. v. 8, n. 4

GERBAUDO, Paolo. (2018) Social media and populism: an elective affinity? Media, Culture \& Society. v. 40, n. 5, pp. 1-9.

GIBSON, James. (1986) The theory of affordances. In: The Ecological Approach to Visual Perception. New Jersey: Lawrence Erlbaum, pp. 127-137.

GLUCKMAN, Max. (1954) Rituals of Rebellion in South-East Africa. Manchester: Manchester University Press.

GRAAN, Andrew; HODGES, Adam; STALCUP, Meg. (2020) Fake news and anthropology: a conversation of technology, trust, and the publics in an age of mass disinformation. PoLAR Online Emergent Conversations: Part 9.

HALL, Kira; GOLDSTEIN, Donna; INGRAM, Matthew (2016) The hands of Donald Trump: entertainment, gesture, spectacle. Hau: Journal of Ethnograpbic Theory. v. 6, p. 2, pp. $71-100$.

KELTY, Christopher. (2005) Geeks, Social Imaginaries, and Recursive Publics. Cultural Antbropology. v. 20, n. 2, pp. 185-214.

KUHN, Thomas. (1970) The Structure of Scientific Revolutions. Chicago: University of Chicago Press.

LACLAU, Ernesto. On populist reason. London: Verso, 2005.

LEMPERT, Michael. (2014) Imitation. Annual Review of Antbropology. v. 43, pp. 379-95.

LUHRMANN, Tanya. (2016) The paradox of Donald Trump's appeal. Sapiens. https:// www.sapiens.org/culture/mary-douglas-donald-trump/

MALY, Ico. (2018) Populism as a mediatized communicative relation: the birth of algorithmic populism. Tilburg Papers in Culture Studies. v. 213. Available at: https://www. tilburguniversity.edu/sites/tiu/files/download/TPCS_213_Maly_2.pdf

MALY, Ico. (2019) New Right Metapolitics and the AlgorithmicActivism ofSchild \& Vrienden. Social Media + Society. Available at: https://doi.org/10.1177/2056305119856700.

MARRES, Nootje. (2018) Why we can't have our facts back. Engaging Science, Technology and Society. v. 4, pp. 423-443. 
MAZZARELLA, William. (2017) The Mana of Mass Society. Chicago: University of Chicago Press.

MAZZARELLA, William. (2019) The anthropology of populism: beyond the liberal settlement? Annual Review of Antbropology. v. 48, pp. 45-60.

MILLER, Daniel et al. (2016) How the World Changed Social Media. Londres: UCL Press.

MIROWSKI, Phillip. (2019) Hell is truth seen too late. Boundary 2. v. 46, n. 1, pp. 1-53.

MOUFFE, Chantal. (2000) The democratic paradox. London: Verso.

NAGLE, Angela. (2017) Kill All Normies: Online Culture Wars from 4chan and Tumblr to Trump and the Alt-Right. New York: Zero Books.

NEMER, David. (2019) A radicalização invisível da direita brasileira no WhatsApp. Huffington Post Brasil, August 20th.

PROCHÁZKA, Ondrej; BLOMMAERT, Jan. (2019) Ergoic Framing in New Right Online Groups: Q, the MAGA Kid, and the Deep State Theory. Tilburg Papers in Culture Studies, v. 224.

SILVA, Daniel. (in press) Enregistering the nation: Bolsonaro’s populist branding of Brazil, In: Theodoropoulou \& J. Woydack (eds) Language and Country Branding. London: Routledge, in print. Available at: https://www.academia.edu/39723047/WP252_ Silva_2019._Enregistering_the_nation_Bolsonaros_populist_branding_of_Brazil

SINHA, Subir. (2017) Fragile Hegemony: Modi, Social Media, and Competitive Electoral Populism in India. International Journal of Communication. v. 11, pp. 4158-4180.

TURNER, Victor. (1970) Forest of symbols: aspects of Ndembo ritual. Ithaca: Cornell University Press.

TURNER, Victor. (1969) Liminality and communitas, In: The Ritual Process: Structure and AntiStructure. Chicago: Aldine Publishing, pp. 94-130.

WAGNER, Roy. (2016) The Invention of Culture. Chicago: Chicago University Press.

WAISBORD, Silvio. (2018) The elective affinity between post-truth communication and populist politics. Communication Research and Practice. v. 4, n. 1, pp. 17-34. 
WALL, Travis; MITEW, Teodor. (2018) Swarm networks and the design process of a distributed meme warfare campaign. First Monday. v. 23, n. 5.

Recebido: 22/03/2020

Aceito: 2/04/2020

Publicado: 13/04/2020 